NBER WORKING PAPER SERIES

WHY ARE CHILDREN POOR?

Victor R. Fuchs

Working Paper No. 1984

NATIONAL BUREAU OF ECONOMIC RESEARCH 1050 Massachusetts Avenue

Cambridge, MA 02138

July 1986

Research for this paper was supported by grants to the National Bureau of Economic Research from the Alfred P. Sloan Foundation and the Rockefeller Foundation. Helpful comments on an earlier version from Perry Beider, Alain Enthoven, Lawrence Fuchs, John Kaplan, Robert Mnookin, John Pencave1, and Michael Wald are gratefully acknowledged. Thanks are also due Joyce Jacobsen for conscientious research assistance. The research reported here is part of the NBER's research program in Labor Studies. Any opinions expressed are those of the author and not those of the National Bureau of Economic Research. 


\title{
Why Are Children Poor?
}

\begin{abstract}
Data from the 1960, 1970, and 1980 Censuses of Population and the Current Population Surveys of 1980 and 1985 are used to describe and analyze the economic position of children with special emphasis on cross-section differences and variation over time in the incidence of poverty. Between 1959 and 1979 the income available to children tended to follow the same pattern as adult income, but between 1979 and 1984 the trends for children were very unfavorable. Poverty rose, average income fell, and income inequality increased. Contrary to popular belief, the increase in femaleheaded households played only a small part in the growth of poverty among children since 1979. Income available to children fell because households with children are highly dependent on labor income--which fell for all age groups. The elderly (65+), who derive 75 percent of their income from nonlabor sources (e.g., social security, private pensions, interest), were the only age group to experience gains in real per capita income during 1979-84. The conclusions about trends in the money income available to children and adults are relatively unchanged when estimates of the value of nonmarket production and in-kind government social welfare programs are added to money income.
\end{abstract}

Victor R. Fuchs NBER 204 Junipero Serra Boulevard Stanford, CA 94305 
WHY ARE CHILDREN POOR?

Victor R. Fuchs

A substantial improvement in the income of elderly Americans is leading some social scientists to redirect attention to the economic problems of children. ${ }^{1}$ This redirection is very timely. Although real income per capita in the United States increased slightly between 1979 and 1984, the proportion of children living in poverty also increased--from 16.6 to 20.9 percent. Among black children, almost half were in poverty in 1984. Concern over the economic position of children stems from an interest in the country's future because resources devoted to children are a major form of private and social investment. In addition, a country that takes pride in providing equality of opportunity needs a better understanding of differences among children in the resources available to them.

Why are children poor? This paper provides several answers to this question, but always in the context of economic poverty. Children can, of course, be poor in other ways as well. Some are physically or mentally abused; some are neglected or exploited. Children can be in poor health, emotionally starved, or deprived of an adequate education. The emphasis on economic measures is not to suggest that the non-economic aspects of childhood are unimportant, but access to a reasonable level of goods and services is usually an important factor in overall well-being--for children as well as for adults.

Even when the inquiry is limited to the economic position of children a precise description is beyond reach because many of the necessary data are not available. For instance, we do not know how the income of individual households is shared within those households, or even how, on average, the 
sharing between adults and children may have changed over time. This paper assumes that household income is shared equal1y among al1 members of a household. Alternative sharing rules would not have much effect on the analysis provided the rule was relatively constant over time and between different types of households. Another possible limitation concerns possible transfers of income between households (e.g., gifts from grandparents). With the exception of alimony and child support payments, this paper omits interhousehold transfers because data are not available. ${ }^{2}$ Although access to goods and services depends on more than money income, most measures of poverty concentrate on money, and that practice is followed here. Toward the end of the paper, however, money income measures are supplemented in two ways. First, an estimate is made of nonmarket production of goods and services within households. Second, the value of in-kind government programs in health, education, and social services is estimated and allocated to children and adults.

The question of economic poverty among children can be explored from several perspectives. One might, for instance, be interested in the absolute level of living of children, in which case the overall state of the economy is surely the most important factor. It is no mystery why the children of India are poor--India is a poor country. In the United States as we 11 , the proportion of children living in poverty tends to change with changes in the economy as a whole. For instance, the incidence dropped almost 10 percentage points between 1959 and 1969, primarily because of the economic boom of the 1960s.

A more interesting analytical question is why the economic position of children differs from that of adults. The answer is to be found in variation in the number of children across households and the relation between this 
variation and the distribution of household income. The importance of number of children can be shown with a simple example. Suppose that every household consists of two adults and three children. In that case there can be no difference between children and adults in available per capita income (assuming equal sharing), regardless of the distribution of income across households. But suppose one-third of the households have two children, onethird three children, and one-third four children (with two adults in each household). If household income is not correlated with size of household, the average income available per child is less than average income per adult because more of the children are in larger households with lower per capita income. In this example, the child/adult income ratio is $.95 .^{3}$ If the variance in household size is greater, say one-fifth of the households each having one, two, three, four, or five children (with two adults per household), the ratio of average income available per child to that of the average adult would be $.86 .^{4}$ A positive correlation between household income and household size would tend to raise the ratio back toward unity, but a negative correlation would decrease it further.

A third type of question concerns differences among children. Why are some children poor and others not? Differences in the number of children per household can be an important part of the answer, but other features of the household such as the age, education, or sex of the adults are also relevant. For instance, how much of the recent growth of poverty among children can be accounted for by an increase in female-headed households? Or, in the light of major reductions in black-white earnings differentials, why is poverty so much more prevalent among black children than among white? This paper uses data from the Censuses of Population of 1960, 1970, and 1980, and the Current Population Surveys of March 1980 and March $1985^{5}$ to shed light on several dimensions of children's poverty. Poverty levels for 
each household in each year are set according to the official Census Bureau weights that establish income thresholds based on the number of adults and number of children in the household. ${ }^{6}$ For instance, a household with two adults and two children has a poverty threshold 1.51 times that of a household with two adults, and 1.95 times a one-adult household. Once a household is identified as having total money income below the poverty threshold, all the individuals in that household are designated as being in poverty. The poverty thresholds are adjusted each year to take account of changes in the price level.

As a supplement to the poverty analysis, the paper also considers trends in the average income available to children (and adults). The average is calculated in two ways. First, the total income of each household is divided by the number of individuals in that household to obtain "per capita" income. No distinction is made between adults and children and there is no allowance for economies of scale. ${ }^{7}$ The second approach, "adjusted per capita income," divides total household income by one if there is one person in the household, and by various multiples of one for other households, depending on the number of adults and number of children present. The multiple is equal to the ratio of the Census poverty level for that particular type of household to the level for a one-person household. For instance, the income in a two-adult, two-child household is divided by 1.95 to obtain adjusted per capita income because the poverty threshold for such a household is 1.95 times the threshold for a one-person household. 8

The next section describes and analyzes cross-section differences and changes over time in the incidence of poverty. Then trends in average income of children and adults and in income inequality are discussed. The final set of results shows how inclusion of nonmarket production and in-kind government programs modifies conclusions based on money income alone. 


\section{$\underline{\text { Results }}$}

\section{The Incidence of Poverty}

The basic statistics describing the incidence of poverty among children and adults over the past quarter-century are set out in Table 1 . We see that the trends for children and adults, and whites and blacks, generally follow a similar pattern: huge declines in poverty during the prosperous 1960s, much smaller declines in the 1970s (with a small increase for white children), and increases in the 1980s. There are, however, interesting differences in both levels and trends. In every year the level of poverty is always much higher for children than for adults, and much higher for blacks than for whites. The relative gap between children and adults has tended to increase since 1969 (especially for whites) while the relative gap between the races has declined for children while remaining approximately constant for adults. The tables that follow provide some understanding of the sources of these differences in levels and trends.

The data in Table 2 help answer the question "Why are children poor relative to adults?" We see that there is considerable variation in the number of children per household; in 1959 the actual distribution was not very far from one-fifth in each of five different size classes. This variation would not put children at a disadvantage if household income rose proportionately with the number of children, but the correlation is actually in the opposite direction: household income falls in the larger households, and therefore per capita income falls precipitously. Even after adjustment for economies of scale, per capita income is much lower in the households with many children.

In contrast to children, only a small percentage of adults live in the households with many children, and by 1984 well over half of all adults were 
Table 1. Percent in poverty, children and adults, by race, selected years, 1955-84.

\begin{tabular}{|c|c|c|c|c|c|}
\hline & \multicolumn{3}{|c|}{ Census } & \multicolumn{2}{|c|}{ CPS } \\
\hline & 1959 & 1969 & 1979 & 1979 & 1984 \\
\hline \multicolumn{6}{|l|}{ A11 races } \\
\hline Children & 25.9 & 16.2 & 15.9 & 16.6 & 20.9 \\
\hline Adults & 19.4 & 12.4 & 10.1 & 10.0 & 11.2 \\
\hline Children minus adults & 6.5 & 3.8 & 5.8 & 6.6 & 9.7 \\
\hline Children divided by adults & 1.34 & 1.31 & 1.57 & 1.66 & 1.87 \\
\hline
\end{tabular}

\section{Whites}

Children
Adults

Children minus adults

Children divided by adults

$\begin{array}{rrrrr}20.4 & 11.6 & 12.2 & 13.2 & 17.4 \\ 16.8 & 10.6 & 8.5 & 8.6 & 9.7 \\ 3.6 & 1.0 & 3.7 & 4.6 & 7.7 \\ 1.21 & 1.09 & 1.44 & 1.53 & 1.79\end{array}$

\section{$\underline{\text { Blacks }}$}

Children

Adults

Children minus adults

Children divided by adults

$\begin{array}{ccccc}64.7 & 44.8 & 36.8 & 41.5 & 45.3 \\ 45.1 & 29.2 & 23.9 & 24.9 & 26.2 \\ 19.6 & 15.6 & 12.9 & 16.6 & 19.1 \\ 1.43 & 1.53 & 1.54 & 1.67 & 1.73\end{array}$

$\begin{array}{lll}64.7 & 44.8 & 36.8\end{array}$

1.73

Blacks minus Whites

Children

Adults

$\begin{array}{lllll}44.3 & 33.2 & 24.6 & 28.3 & 27.9 \\ 28.3 & 18.6 & 15.4 & 16.3 & 16.5\end{array}$

\section{Blacks divided by Whites}

$\begin{array}{llllll}\text { Children } & 3.17 & 3.86 & 3.02 & 3.14 & 2.60 \\ \text { Adults } & 2.68 & 2.75 & 2.81 & 2.90 & 2.70\end{array}$


Table 2. Distributions of children and adults and relative household income by number of children in household, 1959-84.

\begin{tabular}{|c|c|c|c|c|c|c|}
\hline & & \multicolumn{3}{|c|}{ Census } & \multicolumn{2}{|c|}{ CPS } \\
\hline & & 1959 & 1969 & 1979 & 1979 & 1984 \\
\hline \multicolumn{7}{|l|}{$\underline{\text { Percent of Children }}^{a, b}$} \\
\hline $\begin{array}{l}\text { Number of children } \\
\text { in household }\end{array}$ & $\begin{array}{l}1 \\
2 \\
3 \\
4 \\
5+\end{array}$ & $\begin{array}{l}14 \\
26 \\
24 \\
16 \\
20\end{array}$ & $\begin{array}{l}14 \\
26 \\
24 \\
17 \\
19\end{array}$ & $\begin{array}{r}20 \\
36 \\
25 \\
12 \\
8\end{array}$ & $\begin{array}{r}20 \\
36 \\
23 \\
12 \\
9\end{array}$ & $\begin{array}{r}21 \\
38 \\
23 \\
10 \\
7\end{array}$ \\
\hline Mean Household Income & 1984) & 21,333 & 27,575 & 28,348 & 27,308 & 26,897 \\
\hline \multicolumn{7}{|c|}{ Household Income Relative to Mean } \\
\hline $\begin{array}{l}\text { Number of children } \\
\text { in household }\end{array}$ & $\begin{array}{l}0 \\
1 \\
2 \\
3 \\
4 \\
5+\end{array}$ & $\begin{array}{r}90 \\
110 \\
114 \\
113 \\
105 \\
89\end{array}$ & $\begin{array}{r}88 \\
111 \\
117 \\
118 \\
112 \\
100\end{array}$ & $\begin{array}{r}91 \\
112 \\
117 \\
113 \\
101 \\
90\end{array}$ & $\begin{array}{r}91 \\
114 \\
116 \\
111 \\
101 \\
93\end{array}$ & $\begin{array}{r}95 \\
112 \\
111 \\
102 \\
93 \\
77\end{array}$ \\
\hline \multicolumn{7}{|l|}{$\underline{\text { Percent of Adults }}^{a, b}$} \\
\hline $\begin{array}{l}\text { Number of children } \\
\text { in household }\end{array}$ & $\begin{array}{l}0 \\
1 \\
2 \\
3 \\
4 \\
5+\end{array}$ & $\begin{array}{r}46 \\
18 \\
17 \\
10 \\
5 \\
5\end{array}$ & $\begin{array}{r}50 \\
17 \\
15 \\
9 \\
5 \\
4\end{array}$ & $\begin{array}{r}56 \\
18 \\
16 \\
7 \\
3 \\
1\end{array}$ & $\begin{array}{r}54 \\
18 \\
16 \\
7 \\
3 \\
2\end{array}$ & $\begin{array}{r}57 \\
18 \\
15 \\
6 \\
2 \\
1\end{array}$ \\
\hline
\end{tabular}

aistributions as of $1960,1970,1980$, and 1985.

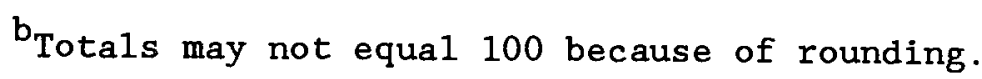


in households that had no children. These adults had an adjusted (for economies of scale) per capita income that was 57 percent greater than the average available to children; the unadjusted difference in per capita income was 110 percent.

Each period since 1959 had its own distinctive pattern of change. During the 1960s the distribution of number of children remained very stable while the negative correlation between household size and income diminished. This tended to help children relative to adults. Between 1969 and 1979 the income correlation became more negative, offsetting a big reduction in the proportion of children living in large households. Between 1979 and 1984 the distribution of number of children was again stable while the relative income position of the households with many children deteriorated further. Taking the 25-year period as a whole, a reduction in the proportion of children living in large households tended to help the economic position of children, but a fall in the relative income of households with many children tended to hurt them. The increasing proportion of adults who lived apart from children and the increase in the relative income of those households contributed to the widening gap between adults and children. To gain further insights concerning these trends, we turn to a multivariate analysis where the number of children per household is considered simultaneously with other household characteristics.

To set the stage for the multivariate analysis, we note in Table 3 that the proportion of children in poverty varies not only with race and number of children but also with region, sex and marital status of the adults in the household, as well as the education and age of the householder (head of household). Poverty rates for children are particularly high for blacks, and in households that do not have an adult male, that have five or more 
Table 3. Percent of children in poverty, by characteristics of household.

\begin{tabular}{|c|c|c|c|c|c|c|}
\hline & & \multicolumn{3}{|c|}{ Census } & \multicolumn{2}{|c|}{ CPS } \\
\hline & & 1959 & 1969 & 1979 & 1979 & 1984 \\
\hline \multicolumn{2}{|l|}{$\begin{array}{l}\text { White } \\
\text { Black }\end{array}$} & $\begin{array}{l}20.4 \\
64.7\end{array}$ & $\begin{array}{l}11.6 \\
44.8\end{array}$ & $\begin{array}{l}12.2 \\
36.8\end{array}$ & $\begin{array}{l}13.2 \\
41.5\end{array}$ & $\begin{array}{l}17.4 \\
45.3\end{array}$ \\
\hline \multicolumn{2}{|l|}{$\begin{array}{l}\text { Non-South } \\
\text { South }\end{array}$} & $\begin{array}{l}18.2 \\
41.9\end{array}$ & $\begin{array}{l}12: 2 \\
24.9\end{array}$ & $\begin{array}{l}14.0 \\
19.7\end{array}$ & $\begin{array}{l}14.6 \\
21.4\end{array}$ & $\begin{array}{l}19.7 \\
23.8\end{array}$ \\
\hline \multicolumn{2}{|c|}{$\begin{array}{l}\text { Married couple in household } \\
\text { No man in household } \\
\text { Other households }\end{array}$} & $\begin{array}{l}22.2 \\
72.2 \\
43.1\end{array}$ & $\begin{array}{l}10.7 \\
56.9 \\
29.6\end{array}$ & $\begin{array}{r}9.3 \\
51.5 \\
25.0\end{array}$ & $\begin{array}{r}9.8 \\
52.9 \\
20.1\end{array}$ & $\begin{array}{l}13.0 \\
57.6 \\
23.5\end{array}$ \\
\hline Number of children & $\begin{array}{l}1 \\
2 \\
3 \\
4 \\
5+\end{array}$ & $\begin{array}{l}14.3 \\
14.3 \\
19.6 \\
28.0 \\
54.7\end{array}$ & $\begin{array}{r}9.3 \\
9.1 \\
11.8 \\
17.6 \\
35.1\end{array}$ & $\begin{array}{r}9.8 \\
11.0 \\
16.2 \\
25.1 \\
39.6\end{array}$ & $\begin{array}{r}9.4 \\
10.8 \\
17.6 \\
24.9 \\
41.4\end{array}$ & $\begin{array}{l}12.7 \\
15.2 \\
23.5 \\
34.2 \\
49.4\end{array}$ \\
\hline $\begin{array}{r}\text { Education of househ } \\
<9 \text { year } \\
9-11 " \\
12 \\
13-15 " \\
\geq 16\end{array}$ & $\begin{array}{l}\text { older } \\
s\end{array}$ & $\begin{array}{r}46.0 \\
24.2 \\
14.6 \\
9.1 \\
4.7\end{array}$ & $\begin{array}{r}34.2 \\
20.7 \\
10.1 \\
6.8 \\
2.8\end{array}$ & $\begin{array}{r}35.3 \\
28.9 \\
13.3 \\
8.8 \\
3.0\end{array}$ & $\begin{array}{r}39.1 \\
29.4 \\
13.0 \\
8.3 \\
3.5\end{array}$ & $\begin{array}{r}47.5 \\
41.7 \\
18.4 \\
12.0 \\
4.4\end{array}$ \\
\hline Age of householder & $\begin{array}{l}<25 \\
25-34 \\
35-44 \\
45+\end{array}$ & $\begin{array}{l}36.7 \\
24.3 \\
23.7 \\
29.4\end{array}$ & $\begin{array}{l}27.0 \\
16.0 \\
14.3 \\
17.2\end{array}$ & $\begin{array}{l}34.5 \\
17.2 \\
12.8 \\
14.7\end{array}$ & $\begin{array}{l}31.9 \\
17.2 \\
13.9 \\
16.6\end{array}$ & $\begin{array}{l}45.3 \\
23.4 \\
16.3 \\
20.0\end{array}$ \\
\hline Al1 & & 25.9 & 16.2 & 15.9 & 16.6 & 20.9 \\
\hline
\end{tabular}


children, and where the householder has less than nine years of education or is under 25 years of age.

The relationship between children's poverty and each of these variables, holding constant the levels of the other variables, is shown in Table 4, which reports the results of regressing poverty status (a dichotomous variable) on a series of dummy variables representing the household characteristics. Logit regressions estimated by maximum likelihood are theoretically preferable to the OLS method reported in Table 4, but the results when evaluated at the means of the variables are sufficiently close to the OLS results that the latter are reported here to simplify the exposition. 9

The multivariate approach sharply reduces the influence of some variables such as race and region, while others such as the absence of a man in the household remain very large. Many of the coefficients are stable across the years, but region and race show substantial change. In 1959, ceteris paribus, there was a 13 percentage point differential between Southern children and other children in the probability of being in poverty. By 1984 the regional differential had completely disappeared. The coefficient for black fell in half between 1959 and 1979, but showed no further decline between 1979 and 1984.

We saw in Table 2 that the distribution of children by size of household changed markedly between 1969 and 1979 and that this change, ceteris paribus, would tend to increase the income available per child. Other compositional changes that affected children were also occurring, as shown in Table 5. Of particular relevance was a shift of children from households with a married couple to those with no man, and an increase in the proportion of children living with householders who had completed 12 years or more of schooling. The information about changes in the 
Table 4. Results of regressing poverty status on household characteristics (OLS partial regression coefficients).

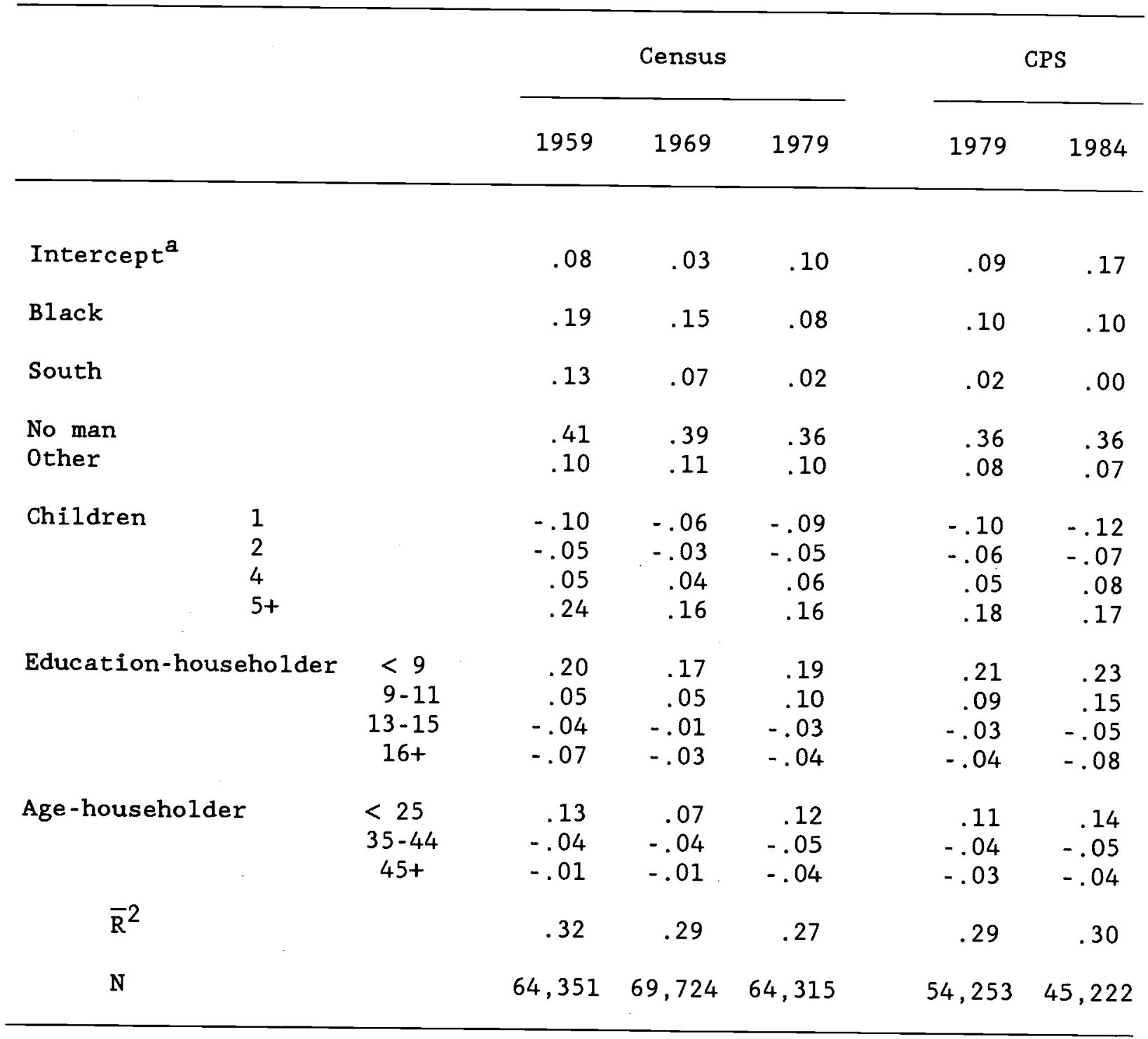

* Al1 coefficients different from zero with probability $>.99$ except South in 1984 .

${ }^{a}$ Omitted group is white, non-South, married couple, three children, head 12 years of schooling and age 25-34. 
Table 5. Percent distribution of children by characteristics of household.

\begin{tabular}{|c|c|c|c|c|c|c|}
\hline & & \multicolumn{3}{|c|}{ Census } & \multicolumn{2}{|c|}{ CPS } \\
\hline & & 1959 & 1969 & 1979 & 1979 & 1984 \\
\hline $\begin{array}{l}\text { White } \\
\text { Black }\end{array}$ & & $\begin{array}{l}88 \\
12\end{array}$ & $\begin{array}{l}86 \\
14\end{array}$ & $\begin{array}{l}85 \\
15\end{array}$ & $\begin{array}{l}88 \\
12\end{array}$ & $\begin{array}{l}88 \\
12\end{array}$ \\
\hline $\begin{array}{l}\text { Non-South } \\
\text { South }\end{array}$ & & $\begin{array}{l}68 \\
32\end{array}$ & $\begin{array}{l}69 \\
31\end{array}$ & $\begin{array}{l}66 \\
34\end{array}$ & $\begin{array}{l}70 \\
30\end{array}$ & $\begin{array}{l}71 \\
29\end{array}$ \\
\hline $\begin{array}{l}\text { Married couple } \\
\text { No man in household } \\
\text { Other }\end{array}$ & & $\begin{array}{r}91 \\
6 \\
3\end{array}$ & $\begin{array}{r}85 \\
10 \\
4\end{array}$ & $\begin{array}{r}80 \\
13 \\
6\end{array}$ & $\begin{array}{r}79 \\
14 \\
7\end{array}$ & $\begin{array}{r}76 \\
16 \\
8\end{array}$ \\
\hline Education of householder & $\begin{array}{c}<9 \\
9-11 \\
12 \\
13-15 \\
16+\end{array}$ & $\begin{array}{r}34 \\
21 \\
25 \\
9 \\
10\end{array}$ & $\begin{array}{l}22 \\
21 \\
32 \\
11 \\
14\end{array}$ & $\begin{array}{l}13 \\
16 \\
36 \\
17 \\
18\end{array}$ & $\begin{array}{l}14 \\
15 \\
37 \\
16 \\
18\end{array}$ & $\begin{array}{l}12 \\
13 \\
37 \\
18 \\
20\end{array}$ \\
\hline Age of householder & $\begin{array}{r}<25 \\
25-34 \\
35-44 \\
45+\end{array}$ & $\begin{array}{r}4 \\
30 \\
39 \\
26\end{array}$ & $\begin{array}{r}5 \\
30 \\
39 \\
26\end{array}$ & $\begin{array}{r}6 \\
34 \\
38 \\
22\end{array}$ & $\begin{array}{r}5 \\
35 \\
37 \\
23\end{array}$ & $\begin{array}{r}5 \\
35 \\
41 \\
19\end{array}$ \\
\hline
\end{tabular}


distribution of children by household characteristics can be combined with the regression coefficients reported in Table 4 to get some sense of the relation between these compositional changes and the overall change in poverty among children.

Table 5 reports the results of such a statistical decomposition for each of the three periods. These figures were obtained in the following way: the change in the proportion of children in each group between each pair of years was multiplied by the average of the coefficients for that group in the two years. For example, the regression coefficients for South in 1959 and $1969, .13$ and .07 , te 11 us that, ceteris paribus, during this period living in the South added, on average, 10 percentage points to the probability of a child being in poverty. Thus the decline of one percentage point (from 32 to 31 percent) in the proportion of children actual1y 1 iving in the South would, ceteris paribus, have produced an overall decline in children's poverty of 0.1 percentage points $(0.1 \times 1.0)$.

Similar calculations were made for each variable and, in the case of a set of related dummy variables such as number of children, the results were aggregated to show the total change in poverty implied by the regression coefficients and the changes in distribution of children. The change in the intercept between two regressions shows the change in poverty implied for the omitted group, i.e., white, non-South, married couple, three children, householder with 12 years of schooling, and aged 25-34. The sum of all the changes minus the actual change in percent in poverty yields the unallocated change. This reflects changes in the poverty rates of other groups relative to the omitted group (i.e., changes in the regression coefficients) as we 11 as changes not captured by this statistical decomposition. This accounting framework is suggestive of the principal variables associated with changes 
in poverty among children, but it cannot be interpreted as providing proof of causality. Changes in some variables, such as the number of children per household or the proportion of female households, are treated in this framework as exogenous, but they themselves may be determined by changes in household income.

Looking at the results for 1959-69 we see that the most important compositional changes were the shift in sex and marital status of adults, which tended to increase poverty in children, and the increase in the education of householders, which tended to reduce poverty. In 1969-79 these variables continued to act in the same way, but the shift in the distribution of children by number in household was also a major factor tending to reduce children's poverty. In the most recent period, 1979-84, al1 three of these variables were at work, but the net effect of the compositional shifts was very smal1. Perhaps the most important inference to be drawn from Table 6 is that the growth of female households can account for only a small part of the recent increase in poverty among children. This conclusion is confirmed by a separate calculation: when children in female households are eliminated from both the 1979 and 1984 samples, the remaining children show a 3.3 percentage point increase in the incidence of poverty between those years. This deterioration in the economic position of children is explored in greater detail later in this paper.

Poverty has always been much more widespread among black than white children. Why is this so? In particular, how much of the differential can be accounted for by race differences in size of household, sex and marital status of adults in household, education of householder, and so on? The method of statistical decomposition used to analyze changes in poverty over time can also be used to account for the black-white differential in poverty at given points in time. The results reported in Table 7 were obtained by 
Table 6. Statistical accounting of changes in percent of children in poverty between selected years 1959-84.

\begin{tabular}{llll}
\hline & $1959-69$ & $1969-79$ & $1979-84$ \\
\hline & & & \\
& & -0.3 & +4.3 \\
Change in percent in poverty & -9.7 & & \\
& & & 0.0 \\
Change associated with change in & & +0.1 & 0.0 \\
distribution of children by: & -0.1 & +0.1 & +0.7 \\
Region & +0.2 & +1.4 & -0.9 \\
Race & +1.7 & -2.9 & -0.9 \\
Sex and marital status of adults & -0.2 & -2.3 & -0.1 \\
Number of children in household & -2.5 & +0.2 & -2.0 \\
Education of householder & +0.1 & +6.9 & +7.5 \\
Age of householder & -5.5 & & \\
&
\end{tabular}

Note: For method of calculation, see text.

amplied poverty rate of omitted group: white, non-South, married couple, householder, 12 years of schooling, and age 25-34.

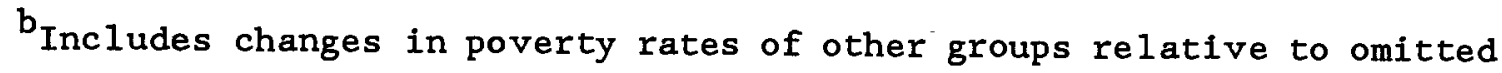
group. 
Table 7. Statistical accounting of black-white differences in percent of children in poverty, selected years 1959-84.

\begin{tabular}{|c|c|c|c|c|c|}
\hline & \multicolumn{3}{|c|}{ Census } & \multicolumn{2}{|c|}{ CPS } \\
\hline & 1959 & 1969 & 1979 & 1979 & 1984 \\
\hline $\begin{array}{l}\text { Difference in percent } \\
\text { in poverty }\end{array}$ & 44.3 & 33.2 & 24.6 & 28.3 & 27.9 \\
\hline \multicolumn{6}{|l|}{$\begin{array}{l}\text { Difference associated with } \\
\text { difference in distribution } \\
\text { of children by: }\end{array}$} \\
\hline Region & 4.6 & 1.8 & 0.4 & 0.5 & 0.0 \\
\hline Sex and marital status & 5.1 & 7.7 & 8.8 & 10.7 & 11.1 \\
\hline Number of children & 8.0 & 4.1 & 3.0 & 2.7 & 2.3 \\
\hline Education of householder & 7.4 & 4.5 & 3.5 & 3.7 & 4.1 \\
\hline Age of householder & 0.2 & 0.5 & 0.6 & 0.6 & 0.7 \\
\hline $\begin{array}{l}\text { Difference, holding constant } \\
\text { the other variables }\end{array}$ & 19.0 & 14.6 & 8.3 & 10.1 & 9.7 \\
\hline
\end{tabular}

${ }^{a}$ This is equal to the partial regression coefficient for black reported in Table 4 . 
multiplying the regression coefficients of Table 5 by the black-white differences in the percentage distribution of children according to the various household characteristics.

We see that in 1959 the poverty rate among black children was 44.3 percentage points greater than among white. The race difference in distribution of children by number of children in household accounted for 8.0 percentage points, the difference in education of householder 7.4 percentage points, and so on. The total differential accounted for by composition differences was 25.3 percentage points. The remainder, 19.0 percentage points, is the black-white differential, holding constant the influence of the other variables.

In 1969 (and all subsequent years) the race difference in sex and marital status became more important and was the largest compositional factor. Race differences in number of children and education of householder became less important and region became much less important. The fact that blacks are disproportionally in the South cannot account for race differences in poverty once the overall regional difference in poverty rates disappears .

In 1979 and 1984 the sex and marital status variables were even more important, both absolutely and relatively. In those years the race difference in these variables accounted for more of the overall differential in poverty than did any other factor. The contrast between 1959 and 1984 in this respect is particularly striking. In the former year the sex and marital status variables accounted for only 12 percent $(5.1 \div 44.3)$ of the race differential in children's poverty. In the most recent year they accounted for 40 percent $(11.1 \div 27.9)$ of the differential. Excluding children in female households, the black-white gap in children's poverty in 1984 is 16 percentage points. 
Average Income and Income Inequality

The poverty measures provide information about the lower end of the income distribution. Additional insights concerning the economic position of children can be obtained from an examination of levels and trends in average income and income inequality. Table 8 shows the average income available to children and adults in 1984 as well as rates of change in average income for the three periods covered in this paper. Both the per capita and adjusted per capita measures are presented.

We see that the level of adjusted per capita income is substantially higher than the unadjusted version because the latter makes no allowance for economies of scale. Thus the difference between the two measures is greater, the larger is the household. When households get smaller over time, as during the 1969-79 period, per capita income rises more rapidly than does the adjusted measure, but comparisons of rates of change between children and adults, whites and blacks, or between subperiods, yield similar qualitative conclusions for both measures. Given the objectives of this paper, probably the most important conclusion to be drawn from Table 8 is that average income available to children grew about as rapidly as adult income until 1979 (and more rapidly for black children), but that since 1979 the trend has been much worse for children than for adults.

The negative experience of children during 1979-84 is largely the result of disparate income trends by age of adult. The elderly (65 and over) did much better than other adults, but only five percent of them 1ive in households with children. By contrast, one-half of adults under age 65 live with children. Between 1979 and 1984 the per capita income of persons 65 and over grew at 2.7 percent per annum, while adults ages 25-64 had zero growth and those ages 18-24 experienced a decline in per capita income of 1.5 percent per annum. 10 
Table 8. Average income available to children and adults, 1959-84.

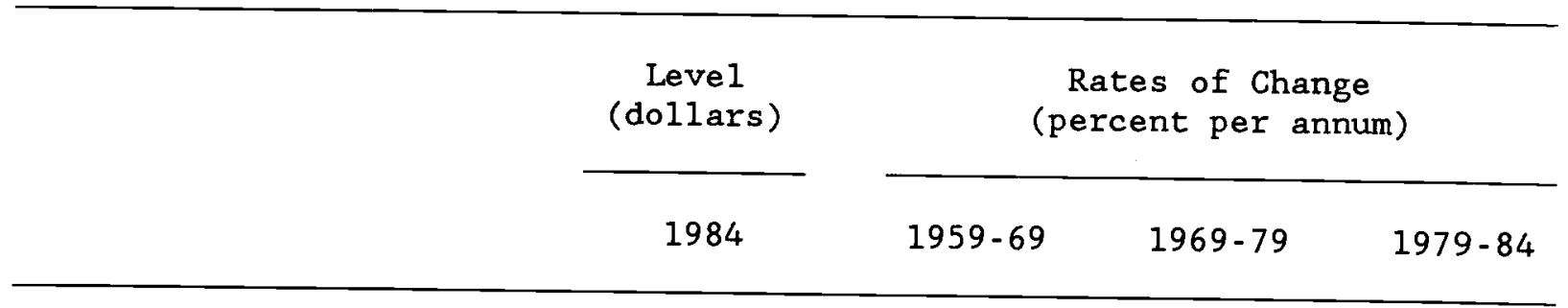

$\underline{\text { Per capita }}$

Al1 races

$\begin{array}{lrrrr}\text { Children } & 6,638 & 3.15 & 1.16 & -0.63 \\ \text { Adults } & 11,287 & 3.18 & 1.25 & 0.24\end{array}$

Whites

$\begin{array}{lrrrr}\text { Children } & 6,993 & 3.12 & 1.08 & -0.64 \\ \text { Adults } & 11,670 & 3.14 & 1.23 & 0.28\end{array}$

Blacks

$\begin{array}{lrrrr}\text { Children } & 4,136 & 4.76 & 2.77 & -0.27 \\ \text { Adults } & 7,515 & 4.17 & 1.92 & 0.17\end{array}$

\section{Adjusted per capita}

Al1 races

$\begin{array}{lllll}\text { Children } & 13,707 & 3.16 & 0.86 & -0.84 \\ \text { Adults } & 19,064 & 2.97 & 0.89 & -0.02\end{array}$

Whites

$\begin{array}{lrrrr}\text { Children } & 14,444 & 3.14 & 0.79 & -0.84 \\ \text { Adults } & 19,705 & 2.93 & 0.87 & 0.02\end{array}$

$\underline{\text { Blacks }}$

\begin{tabular}{lrrrr} 
Children & 8,520 & 4.55 & 2.28 & -0.55 \\
Adults & 12,742 & 3.93 & 1.60 & -0.02 \\
\hline
\end{tabular}


Why did per capita income grow so much more rapidly for the elderly? The answer can be found by disaggregating income into its 1 abor and nonlabor (including transfer) components (see Table 9). Within each category the income of the elderly did not grow more rapidly than the income of other adults; on the contrary, it lagged behind the other groups. Total income grew more rapidly for the elderly because nonlabor income at al 1 ages increased while 1 abor income decreased. ${ }^{11}$ The former accounted for 74 percent of total 1979 income at ages 65+, but only 12 percent and 10 percent at ages 25-64 and 18-24, respectively. In summary, when income is disaggregated into its 1 abor and nonlabor components the rates for children and adults are similar. The disparate trend overall is attributable to the fast-growing nonlabor income accounting for a much larger share of adults' income, especially adults 65 and over.

The unfavorable trend in average income available to children since 1979 has been exacerbated by an increase in income inequality among children. Inequality, as measured by the coefficient of variation (standard deviation divided by the mean), increased between 1979 and 1984 by 4.8 percentage points of the mean after decreasing by 9.4 percentage points between 1959 and 1979. The increase for black children since 1979 was 6.6 percentage points--more than reversing the decrease of 2.4 percentage points in the 20 years prior to 1979 .

In 1984 the coefficient of variation of per capita income available to black children was 93.5 percent, much higher than the 72.8 figure for whites. Much of this differential is attributable to the large proportion of black children living in female households (with low per capita income). Even when these households are excluded, however, income inequality is still greater for black children: 80.6 percent vs. 68.8 percent for white. 
Table 9. Per capita labor and nonlabor income, children and adults, 1979 and 1984.

\begin{tabular}{|c|c|c|c|c|c|c|}
\hline & \multicolumn{3}{|c|}{ Labor } & \multicolumn{3}{|c|}{ Non-1abor } \\
\hline & \multicolumn{2}{|c|}{ Mean leve1 } & \multirow{3}{*}{$\begin{array}{l}\begin{array}{l}\text { Rate of } \\
\text { change }\end{array} \\
\begin{array}{l}\text { (percent } \\
\text { per annum) }\end{array} \\
1979-84\end{array}$} & \multicolumn{2}{|c|}{ Mean level } & \multirow{3}{*}{$\begin{array}{l}\begin{array}{l}\text { Rate of } \\
\text { change }\end{array} \\
\text { (percent } \\
\text { per annum) } \\
1979-84\end{array}$} \\
\hline & (1984 & do1lars) & & (1984 & dollars) & \\
\hline & 1979 & 1984 & & 1979 & 1984 & \\
\hline \multicolumn{7}{|l|}{ Children } \\
\hline A11 & 6,199 & 5,687 & -1.71 & 653 & 951 & 7.81 \\
\hline \multicolumn{7}{|l|}{ Adults } \\
\hline Al1 & 8,950 & 8,282 & -1.54 & 2,205 & 3,006 & 6.39 \\
\hline \multicolumn{7}{|l|}{ Ages: } \\
\hline $18-24$ & 8,950 & 7,865 & -2.55 & 1,012 & 1,351 & 5.96 \\
\hline $25-64$ & 10,434 & 9,809 & -1.23 & 1,468 & 2,111 & 7.53 \\
\hline $65+$ & 2,391 & 2,058 & -2.96 & 6,874 & 8,545 & 4.45 \\
\hline
\end{tabular}




\section{Nonmarket Production and In-Kind Transfers}

The economic position of children (and adults) depends on more than money income. Measured in dollar value, about one-third of the goods and services consumed in American households is produced in those households in the form of meal preparation, housecleaning, child care, and other kinds of nonmarket production. 12 The extent to which children can benefit from such production depends heavily on the presence of adults in the household and on the extent to which those adults are, or are not, also engaged in work outside the home.

During the past quarter-century there have been several significant changes in the living arrangements of children. First, there has been a large increase in the proportion of children living in households with only one adult. This increase was particularly large for black children: by 1985 one out of every three black children (and one out of nine white children) was in such a household. Second, there has been a large increase in the proportion of children in households in which there is no adult out of the labor force. The increase in this category was much greater for white children than for black. Even among those under the age of six, more than one-third of white children lived in households with no adult out of the labor force. These changes tend to reduce the amount of home-produced goods and services.

In order to estimate the nonmarket production of goods and services available to children and adults, ordinary least squares regressions were run on 1975-76 time diary data provided by the University of Michigan's Institute for Social Research. ${ }^{13}$ Separate regression equations for men and women were estimated, with hours of housework (or child care) as the dependent variable. The predictor variables included race, age, marital status, hours of market work, and number and age of children. Average 
housework and child care hours worked by men and women in 1959, 1969, 1979, and 1984 were estimated by applying the 1975-76 cross-section parameters to the characteristics of the individuals in the Census and CPS samples in the respective years. ${ }^{14}$

The value of a nonmarket hour of production was set equal to the individual's hourly wage if the individual worked at least 500 hours in the market. For other individuals, an hour of housework or child care was valued by the average hourly wage earned by market workers of the same sex, race, age, and education. The value of housework was allocated to children and adults on a per capita basis exactly the same way as money income was allocated. The value of child care hours was allocated only to children; the household's total child care was divided by the number of children.

Over the full 25-year span the growth of per capita nonmarket income of children lagged slightly behind that of adults (see Table 10). This is attributable to the shift of children into female households and of adults into households without children. When nonmarket and money income are aggregated, the adult-child gap in growth rates is somewhat larger than for either nonmarket or money income alone. The reason is that nonmarket income grew less rapidly than money income for both children and adults, and children are more dependent on nonmarket income than are adults. In 1984 the ratio of nonmarket to money income was .86 for children and only .52 for adults. For children in female households the ratio was 1.16; that is, the value of nonmarket production exceeded that of money income by 16 percent. Inclusion of nonmarket income reduces slightly the adult-child gap for 1979-84 because adults experienced a bigger decline in nonmarket income than did children.

In addition to output produced at home, children (and adults) benefit from the goods and services such as health, education, and social services 
Table 10. Per capita nonmarket and in-kind ${ }^{a}$ income of children and adults, 1959-84.

\begin{tabular}{|c|c|c|c|}
\hline & $\begin{array}{c}\text { Level } \\
\text { (dollars) }\end{array}$ & \multicolumn{2}{|c|}{$\begin{array}{l}\text { Rate of change } \\
\text { (percent per annum) }\end{array}$} \\
\hline & 1984 & $1979-84$ & $1959-84$ \\
\hline
\end{tabular}

Nonmarket

Children

Adults

Nonmarket plus money

Children

Adults

In-kind social welfare

Children

Adults

$\underline{\text { In-kind plus money }}$

Children

Adults

In-kind plus nonmarket

plus money

Children
Adults

Money only

Children

Adults
5.792

5,861

$-0.86$

$-1.12$

0.78

0.96
Rate of change

percent per annum)

- 
that are provided in kind by government. The value of these goods and servi es is typically not included in official measures of income or pove ty, and have not been included in the measures presented thus far. Tal ?.e 10, however, provides rough estimates of the value of these expenditures and shows how trends in such governmental spending have affected the economic position of children in comparison to adults.

Total expenditures for social welfare by federal, state, and local governments amounted to $\$ 642$ billion in $1983 .^{15}$ of that total, approximately \$312 billion represented cash transfers such as social security retirement income, public employee retirement income, and veterans' pensions. These expenditures are already included in the money income measures and do not enter into the following discussion.

Of the remaining $\$ 330$ billion of social welfare expenditures, approximately $\$ 145$ billion (44 percent) was spent for goods and services provided to children, and $\$ 185$ billion (56 percent) for goods and services provided to adults. These estimates are subject to some error, but probably not much because most of the major categories of expenditures are for programs that are exclusively for children or exclusively for adults. Those that are exclusively for children totaled $\$ 116$ billion, of which $\$ 110$ billion was for elementary and secondary education (including construction) and the balance for child nutrition, maternal and child health, and child welfare programs. Many other government programs such as Medicare ( $\$ 57$ billion) and higher education ( $\$ 32$ billion) provide services almost exclusively for adults. The total value of such programs in 1983 was $\$ 106$ billion.

A third category of programs, such as Medicaid, housing, food stamps, and the like, provide goods and services to adults and children. Their 
aggregate value in 1983 was $\$ 108$ billion. Assuming that children and adults benefited equally from these programs on a per capita basis, ${ }^{16}$ approximately $\$ 29$ billion was for the benefit of children and $\$ 79$ billion for adults. In 1959 over 60 percent of in-kind social welfare expenditures were exclusively for children (mostly education) and the balance divided equally between programs that were exclusively for adults and those that served both adults and children.

During 1959-84 the rate of growth of such expenditures on a per capita basis was more than twice as rapid for adults as for children. In 1979-84 the rate of decline was more rapid for children than for adults. When these in-kind social welfare expenditures are added to money income, however, the differential rates of change between children and adults are similar to those for money income. This is also true when all three sources are aggregated, except that the gap between children and adults during 1979-84 is 0.37 percent per annum smaller than for money income alone.

\section{$\underline{\text { Summary }}$}

Poverty among children was more widespread in 1984 than in 1979 or 1969; the rate of increase during 1979-84 was almost as rapid as the rate of decrease from 1959 to 1969. Contrary to popular belief, the increase in female-headed households played only a small part in the growth of poverty among children since 1979. The biggest factor was a fall in average income available to children in all kinds of households; a second factor was an increase in income inequality. Income available to children fell because households with children are highly dependent on labor income--which fell for all age groups. The elderly $(65+)$, who derive 75 percent of their income from nonlabor sources (e.g., social security, private pensions, interest), 
were the only age group to experience gains in real per capita income during $1979-84$.

In 1984 the poverty rate among black children was 45 percent, compared with 17 percent for white. A substantial portion of this differential (two-fifths) is accounted for by the race difference in proportion of children living in female households. About one-fourth is accounted for by race differences in education and number of children in the household.

Between 1969 and 1979 the proportion of children (all races) living in households with four or more children dropped from 36 to 20 percent. Other things equal, the decrease in large households helps the economic position of children because per capita income tends to be lowest in those households. Between 1979 and 1984 there was a very small decline, and, given the present low fertility rate, there does not seem to be much possibility of further improvement in the economic position of children from that source. The conclusions about trends in the money income of children and adults are relatively unchanged when estimates of the value of nonmarket production and in-kind government social welfare programs are added to money income. 
FOOTNOTES

1. See Samuel H. Preston, "Children and the Elderly: Divergent Paths

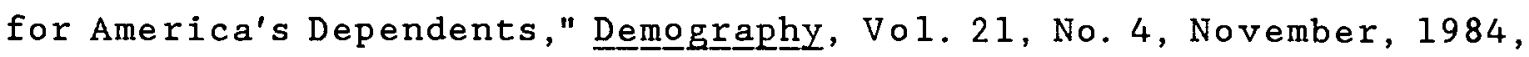
pp. 435-457; also Sheldon Danziger and Peter Gottschalk, "Families with Children Have Fared Worst," Challenge, March-April, 1986, pp. 40-47.

2. Fragmentary data from a household survey sponsored by the President's Commission on Pension Policy suggests that these transfers are not large relative to conventional household income. In August 1979, 18.4 percent of the households acknowledged receiving a transfer during the first eight months of that year. The average transfer was a bit over $\$ 2,000$, which neans that the average transfer spread over all households would have been about $\$ 400$. Only 27 percent of the recipient families had a child age 18 or under. See Donald Cox and Fredric Raines, "Interfamily Transfers and Income Redistribution," in Martin David and Timothy Smeeding (eds.), Horizonta1 Equity, Uncertainty, and Economic Well 1 -Being, Studies in Income and Wealth, Vol. 50, National Bureau of Economic Research, Chicago, University of Chicago Press, 1985, pp. 393-421.

3. If per capita income in the three-child households is set equal to 100 , it would be 125 in the two-child households and 83.33 in those with four children. Average income per adult would be 102.78, but only 98.15 per child because $4 / 9$ of the children are in the larger households and only $2 / 9$ in the smaller ones.

4. If children required less income than adults, the effect of variance in the number of children per household would be diminished, but would still work in the same direction. For instance, if each child required only one-half the income of an adult, the .86 ratio derived in the text would rise to .90 . 
5. Because the samples and survey methods differ somewhat between the Current Population Survey and the Censuses, the change between the 1980 and 1985 Surveys is linked to the changes in the earlier Censuses to facilitate comparison between 1959 and 1984.

6. The official poverty statistics are actually based on families rather than households, but given the marked changes in the legal status of adults who share the same household it seems more appropriate to use a household approach throughout the period. The poverty threshold for a twoadult, two-child household in 1984 was $\$ 10,500$.

7. This is equivalent to the procedure often followed in international comparisons or in tracking economic well-being within a single country over time.

8. This is only one of many possible ways of adjusting for household size and composition. See Terry R. Johnson and John H. Pencave1, "Welfare Payments and Family Composition," in P. K. Robins, R. G. Spiegelman, S. Weiner, and J. G. Bell (eds.), A Guaranteed Annual Income: Evidence from a Socia1 Experiment, New York, Academic Press, 1980, pp. 223-240. The method used in this paper is consistent with the method used to set poverty thresholds for different types of households.

9. In 1959, for instance, the mean deviation between OLS coefficients and those implied by the logit regression is only two percentage points.

10. The rates of growth of adjusted per capita income by age were 2.6 percent, -0.2 percent, and -1.2 percent, respectively.

11. For men about 70 years of age in 1978 over half of nonlabor income came from social security and related government payments; the other major sources were private pensions and interest and dividends. Cf. Michael D. Hurd and John B. Shoven, "Inflation Vulnerability, Income, and Wealth of the 
E] der1y, 1969-1979," in Martin David and Timothy Smeeding (eds.), Horizontal Equity, Uncertainty, and Economic Well-Being, Studies in Income and Wealth, Vo1. 50, National Bureau of Economic Research, Chicago, University of Chicago Press, 1985.

12. Fuchs, 1986, "Sex Differences in Economic We11-Being," Science, Vo1. 232, 25 April 1986, pp. 459-464.

13. Institute for Social Research, Time Use in Economic and Social Accounts, 1975-1976, Ann Arbor, University of Michigan, 1978.

14. See Fuchs (1986) for a fuller discussion of this methodology.

15. See U.S. Statistical Abstracts, 1986 (Superintendent of Documents, Government Printing Office, Washington, D.C.).

16. The final results are relatively insensitive to this assumption. 